\title{
KEY PERFORMANCE INDICATORS AND EMPLOYMENT CONTRACTS IN MALAYSIA: A LEGAL ANALYSIS
}

\author{
Siti Zaharah Jamaluddin* \\ Mohammad Abu Taher** \\ $\mathrm{Ng}$ Seng $\mathrm{Yi}^{* * * *}$
}

\begin{abstract}
Key performance indicators (KPIs) are considered as measurable values used by for companies, institutions, or organisations in order to estimate the success rate of their set objectives. Therefore, it is important to select appropriate indicators that will be used for the measurement. In Malaysia, the KPI came into the spotlight when the Prime Minister introduced it for measuring the performance of the cabinet ministers in 2009. Since then, KPIs became the focus in the private and the public sectors in Malaysia. Thus, this article attempts to examine the values behind KPIs and its function within the contract of employment. The article further examines whether non-performance of KPIs can be categorised as poor performance, which could open employees to termination or disciplinary actions. This article is mainly based on the analysis of existing literature, journal articles, books, information obtained in online news portals and judicial decisions. The article finds that non-performance of KPI can be used as a basis to terminate or dismiss an employee from employment.
\end{abstract}

Keywords: Contract of Employment, Employees, Key Performance Indicators, Poor Performance

Professional 1, Faculty of Law, Multimedia University. Email: sz12789@gmail.com.

** Assistant Professor, Dept. of Law \& Justice, Southeast University, Dhaka. Email: taherlaw16@gmail.com.

Advocate and Solicitor of the High Court of Malaya. Email: ngsengyi0116@gmail.com.

[Received: 6 January 2019, Accepted: 14 February 2019, Published: 30 December 2019] 


\title{
INDEX PRESTASI UTAMA DAN KONTRAK PEKERJAAN: SATU ANALISA PERUNDANGAN
}

\begin{abstract}
ABSTRAK
Index prestasi utama dianggap sebagai nilai yang boleh di ukur yang diguna pakai oleh syarikat-syarikat, institusi atau organisasi bagi mengaggak kejayaan dalam mencapai objektif yang telah ditetapkan. Oleh itu amat penting bagi memilih index atau penunjuk yang sesuai untuk digunakan sebagai kayu pengukur. Di Malaysia, index prestasi utama telah menjadi tumpuan apabila Perdana menteri telah memperkenalkannya bagi mengukur prestasi para menteri cabinet pada tahun 2009. Sejak itu, index prestasi utama telah menjadi tumpuan utama bagi sektor awam dan persendirian di Malaysia. Dengan ini, makalah ini akan memeriksa index prestasi utama dan penggunaannya dalam kontrak pekerjaan. Makalah ini seterusnya turut memeriksa samada ketidak patuhan kepada index prestasi utama boleh dianggap sebagai prestasi buruk, yang boleh menyebabkan seseorang pekerja ditamatkan perkhidmatan atau dihadapkan dengan tindakan disiplin. Makalah ini ditulis berdasarkan analisa yang telah dibuat keatas penulisan sedia ada, makalah dari penerbitan jurnal, buku-buku yang didapati di alam maya serta keputusan mahkamah. Makalah ini mendapati bahawa ketidak patuhan kepada index prestasi utama boleh digunakan untuk menamatkan perkhidmatan seseorang pekerja.
\end{abstract}

Keywords: Kontrak pekerjaan, pekerja, Index Prestasi Utama, prestasi buruk

\section{INTRODUCTION}

Key Performance Indicators (KPIs) are a set of quantifiable measures that an organisation uses to assess or compare performance for accomplishing its' strategic and operational goals. In Malaysia, the Key Performance Indicators, widely known as KPIs, were introduced for the cabinet ministers in 2009. ${ }^{1}$ With that introduction, the KPI eventually became the main method to measure the success of several

\footnotetext{
${ }^{1}$ Tim Leonard, 'KPIs for Cabinet Ministers', The Sun, 9 April 2009.
} 
organisations in Malaysia. Such type of performance assessments has now become of interest to a wide range of organizations, from both the private and public sectors as well as educational institutions. ${ }^{2}$ In the public sector, the Government of Malaysia, through the Performance Management and Delivery Unit (2010) under the Prime Minister's Department, launched the Government Transformation Programme (GTP) with 6 National Key Result Areas (NKRA) and the Economics Transformation Programme (ETP) with 12 sectors of National Key Economic Areas (NKEA) in 2010. ${ }^{3}$ In this regard, the KPI places emphasis on performance delivery, which is analogous to the 1 Malaysia principles - People First, Performance Now. ${ }^{4}$ It aims to transform Malaysia into a high-income nation by 2020 where economic growth is driven by creativity and innovation, and drive Malaysia into the first world status. ${ }^{5}$

On the other hand, the KPI used in the private sector is always linked to the Balanced Scorecard (BSC), which is widely adopted by Malaysian organisations and Malaysian Government-Linked

\footnotetext{
${ }^{2}$ Mahazril'Aini Yaacob, and Adnan Aminuddin. "The Implementation of Key Performance Indicators (KPIs) in the Malaysian Public Sector." Journal of Administrative Science Vol 8, no. 2 (2011): 53.

${ }^{3}$ Hee Song Ng, and Daisy Mui Hung Kee. "Key Intangible Performance Indicators (KIPs) for Organisational Success: The Literature Review." In Business, Technology, and Knowledge Management in Asia: Trends and Innovations, pp. 211-225. IGI Global, 2013.

${ }^{4}$ In Malaysia, while the barriers to achieving Vision 2020 are considerable, they can be overcome through the dedication of, and collaboration between, the Government and the rakyat. Taking up the challenge, the government has formulated the principles of 1Malaysia, People First, Performance Now as a way to accelerate the performance in order to achieve Vision 2020. 1Malaysia (in Malay it is called Satu Malaysia) was a programme designed by the Prime Minister's office during the Najib administration, that called for the cabinet, government agencies, and civil servants to concentrate on ethnic harmony, national unity, and efficient governance. Improving government efficiency is an important aspect of 1Malaysia. See, Government Transformation Programme, Chapter 3 (Catalysing Vision 2020 through 1 Malaysia, People First, Performance Now) available at <www.pmo.gov.my/GTP/documents/.../GTP\%20Roadmap_Chapter03.pdf> accessed on 9 March 2018, p.54.

${ }^{5}$ Hee Song $\mathrm{Ng}$, above $\mathrm{n} 2$.
} 
Companies (GLCs). ${ }^{6}$ Hence, regardless of whether a person works in the public sector or private sector, the KPI is recognised as the best method to measure an employee's performance in the organisation. ${ }^{7}$ As such, the following section of this article focuses on the concept of KPI (design and measurement). This will be followed by a discussion on the legal effect of non-performance of the KPI as a basis for termination or dismissal of an employee.

\section{CONCEPT OF KEY PERFORMANCE INDICATORS (KPIS)}

The Key Performance Indicators or popularly known as KPIs consists of financial and non-financial measures used by organisations to reveal how successful they were in accomplishing long lasting goals. ${ }^{8}$ In a broader sense, the KPI provides the most important information that enables organisations or its stakeholders to understand whether or not the organisation is on the right track. ${ }^{9}$ The KPI also provides a series of measures against which the internal managers and the external investors can judge the organisation and how it is likely to perform over a period of time..$^{10}$ But, it does not mean that everything, which can be measured is attributable to the KPI.

The measured parameters for ascertaining KPIs must be relevant to the fundamentals of the organisation. For example, if the organisation is a travel agency, what would be the fundamental key

${ }^{6}$ Noor Raudhiah Abu Bakar, Mazlina Mustapha, Madya Dr Nor Aziah Abu Kasim, and Rozita Amiruddin. The use of Key Performance Indicator in Malaysian Government-Linked Company. First International Conference on Economics and Banking 2015 (ICEB-15), at < https://download.atlantispress.com/article/25387.pdf > accessed on 20 February 2018.

7 Zaherawati Zakaria, Zuraini Yaacob, Nazni Noordin, Mohd Zool Hilmie Mohamed Sawal, and Zuriawati Zakaria. "Key performance indicators (KPIs) in the public sector: a study in Malaysia." Asian Social Science 7, no. 7 (2011): 102. Even though KPI is important for both sectors, in this article KPIs for employees in the private sector is mainly highlighted.

${ }^{8}$ Dragana Velimirović, Milan Velimirović, and Rade Stanković. "Role and importance of key performance indicators measurement." Serbian Journal of Management 6, no. 1 (2011): 63-72.

9 http://www.ap-institute.com/Key Performance Indicators, on 24th June 2011.

${ }^{10}$ Ibid. 
indicators to its success? The answer would definitely be the number of tourists who opted for the company's attractive touring packages. ${ }^{11}$ The more the company is able to sell their packages, the more profit the company will gain. Thus, it is important for the company to measure this fundamental key to its success.

As such, the easiest way will be to measure the sales of the packages available at the company. The measurement must only be an indicator to future performance. In order to achieve the company's KPI i.e. to increase the number of clients who subscribed to the packages, every department in the company will have a different role to play but the role must mirror the company's KPI. For example, the procurement department must ensure that it obtains the best rate for hotels, airlines fares and other matters incidental to that of the tour business. The department which is in charge of travelling packages must design a variety of packages, at various rates to cater for the needs of their clients. The packages could be divided into certain categories, such as eco-friendly packages, beach and sea, highland and so on. The sales department must be able to market the packages adequately to meet the set target of the company. Therefore, it is important to have a good advertisement strategy, creative brochures, pleasant communication skills and knowledgeable staff. If all the departments were able to fulfil their KPIs, the company will achieve its KPI too and can make more profit.

KPI also includes Keys Intangible Performance (KIP). KIP is a measurement for the intangible performances such as contributions to the society, ethics and values. ${ }^{12}$ Since KIP also involves measurable parameters, it is important that the components be identified and measured. The KIP component can be easily abused if it is not done with fairness and justice.

${ }^{11}$ It goes without saying that business excellence can be achieved through customer satisfaction. See, Gopal K. Kanji, Abdul Malek Bin A. Tambi, and William Wallace. "A comparative study of quality practices in higher education institutions in the US and Malaysia." Total Quality Management 10, no. 3 (1999): p365.

12 Tajul Ariffin Masron, Zamri Ahmad, and Norizan Baba Rahim. "Key performance indicators vs key intangible performance among academic staff: A case study of a public university in Malaysia." Procedia-Social and Behavioral Sciences 56 (2012): 494-503. 
From the discussion above, it is crucial for various departments in the organisation to work together and in tandem with each other. Identifying the key indicators for KPI and KIP is vital. What is also important is the need to recruit the right employees to handle different portfolios, which are crucial to the success of an organisation.

\section{Designing a valid KPI}

A valid set of KPI comprises of tangible and intangible indicators. As such, it is not easy to design the KPI for the employees. If an employee is able to achieve his KPI, he should also be said to have achieved his KIP. This is because to achieve his KPI, it means that he had shown dedication, honesty, hard work and contribution not only to his organisation but also to the society at large.

Therefore, it is important for the employer to opt for the KPI that are achievable and practical. For example, a public university would have identified teaching, supervision, research, consultation and publication as the tangible components of KPIs ${ }^{13}$ while the intangible indicators could include leadership and administrative duties, networking, community contribution and personal quality. Except for personal qualities, the measurement for other intangible component is done via documentation as proof, which may include, appointment letters, certificates of recognition and other similar documents. However, for personal qualities, it is totally up to the superior officer's discretion. This is where abuse and unfairness could take place since the measurement of the personal quality of a person is subjective in nature.

It could be argued that the KPI is not a measurement per se. It is an indicator that can be used by the organisation to improve itself. The general practice is to determine the KPI for the said year, through communication and discussion between both parties. Once agreed, the parties will be bound by the said KPI for that year.

${ }^{13}$ Ibid. The same criteria are used by University of Malaya for its academic staff. 


\section{Measuring the performance of the KPI}

Once the KPI has been identified, the organisation will have to find a suitable method to measure the performance of the said KPI by the employees. Measurement is the process of quantification and action correlates with performance. ${ }^{14}$ Measures can be objective or subjective. ${ }^{15}$ The former can be independently measured and verified while the latter could not be measured. ${ }^{16}$ Measurement and evaluation is necessary as it gives the employer data for determining the worth of the object being evaluated. ${ }^{17}$

In relation to the KPI and KIP, they are considered as part of Performance management system (PMS) which is a continuous process to identify, align, measure and develop individual and team performance along with organisational goals. ${ }^{18}$ With the PMS, the employee's identified objectives are perfectly linked to the organisation's main goals. If the PMS is properly organised and implemented, it will provide a systematic way of analysing and measuring the employee's current performance. ${ }^{19}$ The PMS will

14 Andy Neely, Mike Gregory, and Ken Platts. "Performance measurement system design: a literature review and research agenda." International journal of operations \& production management 15, no. 4 (1995): 80.

${ }^{15}$ MI Mohamad Ishak, M. S. Suhaida, and M. Y. Yuzainee. "Performance measurement indicators for academic staff in Malaysia private higher education institutions: A case study in UNITEN." In PMA Conference 2009. Available from: https://www.researchgate.net/publication/242174198_PERFORMANCE_M EASUREMENT INDICATORS FOR ACADEMIC STAFF IN MALAY SIA PRIVATE HIGHER EDUCATION INSTITUTIONS A CASE STU DY IN UNITEN [accessed on Feb 12, 2018].

${ }_{16}$ Robert Simons, Antonio Dávila, and Robert S. Kaplan. Performance measurement \& control systems for implementing strategy. Upper Saddle River, NJ: Prentice Hall, 2000, p.12.

17 Sivasailam Thiagarajan, and Paula MacGillis. The guidebook for performance improvement: Working with individuals and organizations. Pfeiffer \& Co, 1997, p.53.

18 Peter M. Glendinning. "Performance management: Pariah or messiah." Public personnel management 31, no. 2 (2002): 161-178.

19 Raemah Abdullah Hashim, Zahidah Akmal binti Ghazali, and Azahari Jamaludin. "Past Performance Evaluation is the First Step toward the Future: A Case Study of a Performance Management System in a Malaysian Multi- 
include, inter alia, objective-setting, performance evaluation, and performance review. ${ }^{20}$ PMS is typically cyclical and continuous for organisational efficiency. ${ }^{21}$ Once the KPI is determined and agreed, the weightage of the components of the KPI must also be agreed. The weightage can be divided according to the objectives agreed by the parties. Sometimes the general components are identified while the details will be as agreed between the parties. Based on this mechanism, marks will be given according to the weightage.

Where the full marks is 100 , an employee is said to have successfully achieve his KPI for the year if he obtained 80-100 marks, those who obtained 50-79 are considered to be competent while getting less than 50 marks would mean that the employee is either poor in performance or is neglectful and incompetent. For example, a public university may opt for this measurement to indicate the competency of its employees: unacceptable performance (achieving 0-20\%), minimally acceptable performance (achieving 20-40 \%), acceptable performance (achieving 50 to 60\%), accomplished performance (achieving 80-100\%) and excellent performance (exceeding 50-75\% of the target) ${ }^{22}$ If the employee failed to achieve acceptable performance, he would be given a chance to improve himself with the required assistance, failure of which he may be asked to leave the employment. The KPI and the weightage is discussed and communicated at the first meeting between the employer and the employee.

The progress of the employee's KPI may be reviewed after 6 months while problems or an obstacle faced by the employee is resolved. At this point, the employer would have a general idea as whether the employee is on track or may pose a problem by the year end. This practice will enable the employer to revisit or revise the KPI from time to time to suit the needs and problems faced by his

National Company." American Journal of Economics 5, no. 2 (2015): 278284.

${ }^{20}$ R Lucas, Lupton B., and Mathieson H. Managing Performance, Human Resource Management in an International Context, Chartered Institute of Personnel and Development (CIPD). 2006. 173-178.

21 Herman Aguinis and Charles A. Pierce. "Enhancing the relevance of organisational behaviour by embracing performance management research." Journal of Organisational Behaviour 29, no. 1 (2007): 139-145.

${ }^{22}$ Measurement of KPI for academic staff at the University of Malaya for 2018. 
employees in achieving them. Where the system is adequately observed and combined with the spirit of cooperation, it allows both parties to achieve a win-win situation. Sadly, the review system for KPI is often a mere formality, as the discussion only last for a few minutes, leaving the employee frustrated and demoralised. Similarly, the KPI system is often entrapped in the "form vs. substance" argument. In other words, the form is emphasised as more important without looking at its substance. As such, this will result in unhappiness at the workplace, which could undermine a peaceful in work environment to the detriment of both the employer and the employees.

\section{KPI FOR THE EMPLOYEES}

The KPI is not confined to the measurement of the goals of the organisation but it is also used to measure the organisation's human capital. This is due to the fact that human capital is a vital determining factor in the success of any organisation. An organisation may have its own legal entity, but without the human capital, it will not be able to function at all. ${ }^{23}$ As such, it is also important for any organisation to measure its human capital in order to achieve its goals.

The KPI, when properly developed, should provide all employees with clear goals and the objectives. The employees must understand, how, they relate to the overall success of the organisation. ${ }^{24}$ Every employee must realise that each and every one of them will contribute to the success of their organisation. Hence, it is no longer a choice for some of the employees to fulfil KPI whilst others refuse to do so. The individual's KPI will ultimately mirror the organisation's KPI in order to ensure the achievement of the organisation's goal.

${ }^{23}$ It has always been asserted that the Head of the company, whether he is known as the Executive Director, General Manager, Managing Director and so on is the alter ego of the company, the one who is responsible for the company's policy and human capital management. See the case of Inchcape (M) Holdings Bhd v R B Gray [1985] 2 MLJ 297.

${ }^{24} \mathrm{~N}$ Lockwood. Maximising human capital: demonstrating HR value with key performance indicators, http://findarticles.com/p/articles/mi_m3495/is_9 51/ai_n2699358/1, on 15 June 2011. 
Before the introduction of the human capital KPI, there had been some kind of measurement through the specific job scope assigned by the employer under the contract of employment. ${ }^{25}$ The employer would underline the requirements of that particular job while the employee is required to fulfil his obligations under his contract of employment. Performance is of obligations attracts rewards such as increment in salary, bonuses or other incentives.

However, this method takes an individualistic perspective, due to its indirect correlation to the overall success of the organisation. It takes on a narrow perspective, in the sense that it is only relevant to that particular employee in his contract of employment. His performance as an employee in that organisation does not have anything to do with the other employees in the same organisation or even with the organisation itself. As such, this has created a perception that it is up to the individual employee to decide whether or not he wants to fulfil his obligations as stipulated in his job scope. In other words, it is perceived that only the individual employee will solely feel the impact of his inability to perform. The negative effect of this is that the employees may perceive that their inability to meet the job scope will not have any negative impact on anyone else, including the employer. This perspective is certainly undesirable as it could lead to the failure to achieve the objectives of the organisation as a whole.

This approach has resulted in some employees fulfilling their obligations under their contracts, whilst others are unable to meet their obligations. The organisation realised that with only some of the employees working towards achieving their obligations, it is not enough to help the organisation to move forward and achieve its goal. It is quite certain that this method of measurement would have enabled the organisation to achieve its goals, if each and every employee is committed to perform his/her part of the work as prescribed in the job scope. Since this method did not maximise the potential growth of the organisation, a new set of method of assessment must be introduced.

25 A contract of employment is a contract entered into between two parties, where one of them agreed to do the work for payment of remunerations by the other. The law had formulated various tests in determining whether a contract is a contract of employment or a contract for services (independent contractor). For further reading see, Norman M Selwyn., and Astra Emir. Selwyn's Law of Employment, 14 ${ }^{\text {th }}$ ed, (Oxford University Press, 2006) 413. 
As a result of this weakness in job scope, the KPI is introduced into the contract of employment of the employees because it is closely connected to the company's performance.

\section{POOR PERFORMANCE OF THE EMPLOYEES}

Since the KPI is introduced in the contract of employment, it is important to determine its value to the employee and his contract of employment. The KPI is used as an indicator to gauge the employee's performance under his contract of employment. It is also used by the employer as a yardstick to justify the allocation of bonuses and increments in salary and promotion. Employees who are able to fulfil their KPI would be rewarded and those who did not do so would feel the pinch in their pockets due to a low percentage of bonus and increments or pay stagnation. Monetary gratification is considered to be the best reward based on performance and reward strategy which assumes that employees are not inherently born with the desire to put in their maximum effort at work. ${ }^{26}$

Unlike misconduct, which could be obvious among employees, poor performance is difficult to define. Poor performance refers to the inability of the employee to perform his job properly or he is neglectful incompetent. ${ }^{27}$ The inability to perform takes place when the employee is not able to perform the tasks that he is assigned to, whilst neglectful incompetence refers to an employee who could do the job, but is not achieving his potential. ${ }^{28}$ Any allegation of poor performance must always be substantiated with evidence by the employer. ${ }^{29}$ If it involves team effort, it could be difficult for the employer to identify the particular employee responsible for the non-performance of an assigned task. Therefore, the employer must have a method to appraise the employee's performance; the result of the appraisal must be made

\footnotetext{
${ }^{26}$ Retributivist believed that punishment or reward should take place in cases where the person deserves it. See, Mary Margaret Mackenzie. Plato on punishment. Univ of California Press, 1985.

${ }^{27}$ Norman, above n 25, 413- 414.

${ }^{28}$ Ibid.

${ }^{29}$ Robert John Reeves v Menteri Sumber Manusia [2000] 1 MLJ 107.
} 
known to the employee, to ensure improvement prior to contract termination. ${ }^{30}$

Since the KPIs are merely an indicator as to the employee's performance in the organisation, failure to achieve the KPIs should reflect whether the employee is incompetent in the performance of the task. At its best, a KPI-failure may show that an employee is negligently incompetent. But, a KPI-failure should not ipso facto form a ground for termination. Nonetheless, the Malaysian employment law ${ }^{31}$ permits termination of an employee via resignation, constructive dismissal and retrenchment as a result of change in business ownership, but it must be subject to procedural justice. ${ }^{32}$

Based on the assumption of 100 per cent measurement of KPIs, an employee who obtained the marks ranging from 80 per cent to 100 per cent will be considered as successfully for the said year. In other words, such employee should be rewarded, vide the payment of bonuses and increment in their salaries or other monetary benefits. Obtaining between 50 per cent to 79 per cent could be interpreted as a competent employee while between 30 per cent to 50 per cent implies that the performance of the employee is considered minimally acceptable and employee with less than 30 per cent score are considered as unacceptable performance..$^{33}$ The last two groups are also referred to as incompetent and neglectful employees respectively.

Faced with these two groups i.e. poor performance and neglectful employees, the law allows the termination or dismissal of the employee, provided that it is done in accordance with the law. The

${ }^{30}$ Somyanarain Nalla Pillai Munusamy \& Anor v City-Link Express (M) Sdn $B h d$ [2008] 2 LNS 0169. To inform the employee beforehand is also required for ensuring the fairness and transparency in their termination. It is also a principle of legality. Under this principle, no crime or punishment can exist without a legal ground. The principle of legality protects individuals from state abuse and unjust interference.

${ }^{31}$ Employment Act 1955.

${ }^{32}$ It means the process of making decisions and their implementation must be fair and just.

${ }^{33}$ Measurement of KPI for academic staff at the University of Malaya for 2018. 
discussion as to what can be done by the employer will be discussed in the preceding part of this article.

\section{Incompetent Employees}

Since the KPI indicates that a particular employee's performance at the workplace is poor, the employer has the right to terminate the employee, however, it must be done in accordance with the law. ${ }^{34}$ Article 5(1) of the Malaysian Federal Constitution provides that, "No person shall be deprived of his life or personal liberty save as in accordance of the law." Personal liberty includes equality as provided in Article 8 of the said Constitution. ${ }^{35}$ Whilst in the case of Tan Teck Seng $v$ Suruhanjaya Perkhidmatan Pendidikan \& Anor ${ }^{36}$, the Court of Appeal held that the right to life includes the right to seek and to continue in public or private service employment subject to the removal, for good cause, by resorting to fair procedure. Thus, an employee will also be given the same protection in relation to his tenure.

As such, the phrase 'in accordance with the law' which include procedural fairness requires the employer to warn the employee of his poor performance and to offer sufficient opportunity to improve before the employee's contract of employment can be terminated. ${ }^{37}$ Therefore, it is important for the employer to lay down measures in relation to the incompetent employees. These measures will also support the employer in fulfilling the requirement, 'in accordance with the law'. The employer in the light of this problem must ask a few important questions; why the employee could not do adequately do the job; is he properly trained to do the job; does he have proper equipment to do the job and whether he has sufficient support and facilities to perform his job? ${ }^{38}$ Once the employer has identified the answers to these questions, then it is important for the employer to take measures to address the problem. For example, if the incompetent employee lacks motivation,

34 Ashgar Ali Mohammed. "Unsatisfactory Work Performance And The Requirement of Warning: The Rule of Fairness." ILR 2, no. i (1998): 2.

${ }^{35}$ Pihak Berkuasa Negeri Sanah v Sugumar Balakrishnan [2002] 3 MLJ 72.

36 [1996] 1 MLJ 261.

${ }^{37}$ Rooftech Sdn BHd v Ho Inn, Penang [1986] 2 ILR 818.

${ }^{38}$ Norman, above n 24, 413. 
then the employer must order him to attend motivational and/or counselling sessions. Where further knowledge or training is required, then the employee must be sent for additional training. ${ }^{39}$ The important factor to be acknowledged is that the employer must assist employee to improve his performance. Only if all these measures were taken and still the employee failed to improve his performance, then the employer has the right to terminate the employee's contract of employment.

\section{Warning of Poor Performance}

The employer must warn the employee of poor performance. ${ }^{40}$ The employer has a choice as to how to communicate the warning either through a written letter or an oral discussion. The most important principle to remember is that the warning is given as a notice to the employee about the poor work performance. This will also act as a timeline for both the employer and the relevant employee, to determine the next cause of actions to be taken. Therefore, the warning must be clear to indicate aspects of work, which require improvement and the appropriate period to do so. ${ }^{41}$ In the case of Choy Kwai Wah v Servo

${ }^{39}$ In the case of Davison $v$ Kent Meters Ltd [1975] IRLR 145, the claimant was dismissed for assembling nearly 500 components in the wrong sequence. She claimed that she had followed the pattern of work in accordance with the instructions received from the charge hand, but the latter denied having shown her how to assemble the parts, and maintained that she was entirely to blame for the errors. The employment tribunal thought that if the charge hand had not shown her what to do, he should have done so, and the mistakes were therefore hardly her fault. Further he should have checked on her performance, and supervised her properly.

${ }^{40}$ This is illustrated in the cases of Tan Cheng Leng $v$ Tropicana Medical Centre (M) Sdn Bhd [2017] 1 ILR 383 and Tan Thean Imm v Al Rajhi Banking \& Investment Corporation (Malaysia) Bhd [2015] 2 LNS 0103 which both adopted the case of Amsteel Mills Sdn Bhd v Koh Cheng Siew [1997] 1 ILR 216 where it was held that to justify a workman's dismissal on the ground of poor performance, the employer has to establish: (i) that the workman was warned about his poor performance; (ii) that the workman was accorded sufficient opportunity to improve; and (iii) that the workman failed to sufficiently improve his performance.

${ }^{41}$ Pinfolds Transport Ltd $v$ New Zealand Distribution and General Workers Union [1991] 1 ERNZ 822(LC). 
Engineering $S d n B h d,{ }^{42}$ the claimant commenced employment with the company as a sales engineer. He was employed with a 3 months' probation period based on the fact that he claimed to have good knowledge of electrical engineering as well as mechanical engineering, with 10 years' working experience in sales of similar products. The company had set the sales target of RM 25,000 per month for all the sales persons including the claimant. The claimant failed to reach the sales target during probation period, and was granted another 3 months through a letter, which also informed him of his poor sales performance, and the company hoped that he would be able to improve in the next 3 months. The employer gave the employee 2 warnings before terminating his contract. This case is to be distinguished from the case of Piccolo Mondo Gasto Sdn Bhd v Philip Edward Maria $\operatorname{Doss}^{43}$ where the allegation of poor performance was not recorded, no warning was given to the claimant thus making his dismissal without just cause or excuse.

Warning is said not to be necessary if it involves an employee who holds a management position due to the fact that by nature of his job, he will be fully aware of what is required of him and fully capable to judge for himself whether he has achieved the said requirement. ${ }^{44} \mathrm{Sir}$ John Donaldson in the case of James $v$ Waltham Holy Cross U.D.C ${ }^{45}$ stated that

“...those employed in senior management may by the nature of their jobs be fully aware of what is required of them and fully capable of judging for themselves whether they are achieving that requirement. In such circumstances, the need for warning and an opportunity for improvement is much less apparent." 46

A warning is also unnecessary if the employee is a skilled employee or a professional as seen in the case of Taylor $v$ Alidair Ltd, ${ }^{47}$ where the employee who was a pilot, made a careless landing causing damage to the aeroplane and was dismissed without a warning. The

42 [2008] 2 LNS 0181.

${ }^{43}$ [2007] 2 LNS 0014.

${ }^{44}$ James v Waltham Holy Cross U.D.C.[1973] ICR 398.

${ }^{45}$ Ibid.

${ }^{46}$ Ibid. This position is followed by recent cases of Wong Yat Meng $v$ Paticolube (M) Sdn Bhd [2016] 4 ILR 293 and MD Zakri Awang v H-Lai Mart Sdn Bhd [2017] 1 ILR 272.

${ }^{47}$ [1978] IRLR 82. 
court was of the opinion that under the circumstances in which the degree of professional skill required is so high and the potential consequences of the smallest departure from that standard are so serious, that any failure to perform in accordance with those standards is enough to justify dismissal.

\section{Sufficient Opportunity to Improve}

The employer must give the employee reasonable time and assistance to help him improve his performance. What amounts to reasonable time depends very much on the case. In the case of Choy Kwai Wah v Servo Engineering $S d n B h d,{ }^{48}$ the claimant was notified of the poor performance during the probation, which was extended for another 3 months. Thereafter, it was confirmed, but he failed to improve himself in his work. In this case, the employer gave the employee reasonable time to improve, but the employee failed to do so. In the case of Somyanarain Nalla Pillai Munusamy \& anor v City-Link Express (M) $S d n B h d,{ }^{49}$ the employees commenced employment with the company as an Audit Officer and were put on 6 months' probation period. Within that time, the company issued show cause letters to the employees, alleging poor performance in general. Both the employees responded to the letter, but were later terminated. The court was of the view that the company failed to give the employees written warning and sufficient opportunity to improve themselves, therefore the terminations were taken to be unjust.

Aside from giving the employee sufficient or reasonable time to improve himself, the employer could also provide training, counselling or mentoring to help the employee to improve his performance. The employee may not be able to improve without additional help from the employer. If the employee requires more training, the employer may order him to attend additional training, put him under the supervision of a more senior employee or create a mentor and mentee system. For example, in the case of Choy Kwai Wah v Servo Engineering Sdn Bhd $d^{50}$ the company brought someone to help the employee to improve his sales performance. The court held that the company was justified in terminating the claimant's contract because even with the help

\footnotetext{
${ }^{48}$ [2008] 2 LNS 0181.

49 [2008] 2 LNS 0169.

50 [2008] 2 LNS 0181.
} 
provided by the company, it did not help to propel the claimant to improve his sales performance.

\section{Alternative Employment}

In a situation where an employee has been found to be incompetent, it is in his job, ${ }^{51}$ the employer has to consider alternative employment more suitable to this particular employee within the organisation. Therefore, termination or dismissal must be the last resort. For example, if a sales executive in a travel agency lacks the requisite public relation skills when dealing with customers as well as uses abusive words when dealing with the customers, the company may provide alternative employment for such an employee. Prior to the alternative employment, the employer must have given a warning letter, sufficient time to improve, soft skill training among others. Before the dismissal, the employer needs to consider the availability of any other post that does not require him to have any contact with customers. If available then he must be offered the job, as an alternative. Where the employee refuses the alternative employment, the employer could be justified to terminate the contract.

The law requires the employer to take all the necessary steps to help incompetent employees to improve their performance and termination or dismissal must be the last resort. This approach is taken because these employees have the potential to achieve a much better performance; they just need a little bit of help to propel them to perform better. $^{52}$

\footnotetext{
${ }^{51}$ Norman, above $\mathrm{n} 25,414$.

${ }^{52}$ In this regard, providing sufficient training can be an effective tool to improve their performance. Generally, training enhances employees' capabilities which is instrumental in improving overall performance of the organization. See, Muslim Amin, Wan Khairuzzaman Wan Ismail, Siti Zaleha Abdul Rasid, and Richard Daverson Andrew Selemani. "The impact of human resource management practices on performance: Evidence from a Public University." The TQM Journal 26, no. 2 (2014): 128.
} 


\section{Neglectful Incompetence}

The employee who falls within this category are those who could/would not improve after warnings or necessary assistance. This is not about poor performance but refusal to perform the assigned job. Such employee knows that he has not been achieving the set target set but at the same time remain unbothered and refused to obey the instructions given or cooperate with the others towards improvement. An employee can be described as neglectful incompetence when he intentionally refused to perform the job properly or disobeyed a legitimate instruction. This would be a clear contradiction of the contract of employment. The refusal to perform or the disobedience of an order would be considered as misconduct contrary to the contract of employment. ${ }^{53}$ Among the most appropriate action against misconduct is to bring a disciplinary procedure against the employee in accordance with the gravity of the conduct. ${ }^{54}$ This procedure must indicate the possibility of dismissal in order to push the employee towards improvement. This disciplinary procedure or domestic inquiry ${ }^{55}$ must fulfil the two legal principles, i.e. the right to be heard and the rule against bias.

${ }^{53}$ Generally, misconduct refers to any breach of discipline and to any act or omission which is inconsistent with the fulfilment of the express or implied conditions of employment. The term 'misconduct' is not defined in any Malaysian labour laws. However, there are some cases where the industrial tribunals including the judicial courts defined misconduct. For example, in Syarikat Kenderaan Melayu Kelantan Sdn Bhd v Transport Workers Union (1990) 1 MLJ 5, the court said "Misconduct refers to conduct so seriously in breach of the accepted practice that, by the standards of fairness and justice, the employers should not be bound to continue the employment." See also, Liew Ken \& Ors v Malayan Thung Pau Bhd I.C. Award 37/94; Malaysian Airlines v Zalizan Idris [2006] 2 LNS 0624.

${ }^{54}$ Ibid.

55 In Malaysia, a domestic inquiry is mandatory for an employee who falls within the ambit of the Employment Act 1955 (Act 265) but it is not so for the others, see the case of Dreamland Corporation Sdn Bhd v Choong Chiu Sooi [1988] 1 MLJ 111. 


\section{The Right to Be Heard ${ }^{56}$}

It is important that the employer who undertakes these measures must fulfil the legal principle of the right to be heard. ${ }^{57}$ This right encompasses the right for the employee to know the allegations against him, ${ }^{58}$ the right to be given reasonable time to prepare his defence against such allegations, ${ }^{59}$ the right to examine the witnesses ${ }^{60}$ and the right to mitigate the sentence. ${ }^{61}$ In the case of neglectful incompetence, the outcome of the KPI will enable the employer to show the employee the allegations of misconduct or non-performance.

\section{The Rules against Bias ${ }^{62}$}

The employer is required to appoint a panel to hear the case against the employee for misconduct. It is important that the panellist and the people involved in this proceeding adhere to the rules against bias. This rule requires the employee not to be prejudiced by the actions of all that are involved in his case. All of them must be independent of each other to ensure that the employee will have a fair hearing. ${ }^{63}$ The test adopted by the court to determine this rule is the likelihood of bias and not actual bias. ${ }^{64}$

${ }^{56}$ B. Surinder Singh Kanda v The Government of Federation of Malaya [1962] 28 MLJ 169.

${ }^{57}$ B. Surinder Singh Kanda v The Government of Federation of Malaya [1962] 28 MLJ 169.

58 Esso Production Malaysia Inc v Maimunah Ahmad \& Anor [2002] 3 CLJ 242.

${ }^{59}$ Ahmad Zailani Junoh v Alam Flora Sdn Bhd[2008] 2 LNS 1104.

${ }^{60}$ Said dharmalingam bin Abdullah v Malayan Breweries (Malaya) Sdn Bhd [1997] 1 MLJ 352.

${ }^{61}$ Ibid.

${ }^{62}$ B Surinder Singh Kanda $v$ The Government of Federation of Malaya [1962] 28 MLJ 169.

63 Trade Ocean Exporters Sdn Bhd, Prai v Puan Chee Pek Kian, Penang I.C.Award 109/1993.

${ }^{64} R v$ Sutherland Justices, Ex: P.M.Carthy [1901] 2 K.B. 357 and adopted by the court in the case of Metropolitan Properties Ltd v Lannon [1968] 3 All ER 304. 
After the hearing, the panel will make a finding and forward its recommendations to the employer. The employer normally has a choice of giving the employee a warning, demotion or dismissal. In this case, a warning will not be suitable since the reason for an inquiry was because of the employer's belief that the employee's situation had exceeded the warning stage. If the employer opts to demote the employee, salary reduction may become necessary. If the choice is dismissal, then the employee can be dismissed immediately. Whatever the choice that the employer chooses, it must always be proportionate to the misconduct. ${ }^{65}$

\section{IMPACT OF DISMISSAL ON THE EMPLOYEE'S RETIREMENT PENSIONS}

For an employee who works in the private service and contribute to the Employees Provident Fund in accordance with the Employees' Provident Fund Act 1991, ${ }^{66}$ the dismissal will not have any impact on his retirement pensions. This is because under this scheme, the employee and employer will contribute monthly to the scheme. As long as he is employed, the contributions will continue. In case of dismissal and inability to secure another position, the contributions will be suspended due to joblessness. Employees are only be eligible to withdraw contributions from the fund when he reaches the age of $55 .{ }^{67}$

65 Mentakab Veneer \& Plywood Sdn Bhd, Pahang $v$ abu Bakar bin MoinoiddinI.C. Award 88/1993 and Bank of Commerce (M) Sdn BHd ( formerly known as United Asian Bank Bhd) v Joseph Amirtharajy, S. Perai [1994]1 ILR 523.

66 (Act 452).

${ }^{67}$ Section 54 of the Employees' Provident Fund Act 1991 which allows the contributor to withdraw all his money upon death, physically or mentally incapacitated from engaging in an employment or, if the contributor is not a citizen, he is about to leave Malaysia. 
This rule could vary for an employee who works in the public service $^{68}$ and who is a pensionable officer. ${ }^{69}$ Section 3 of the Pensions Act $1980^{70}$ provides that: ${ }^{71}$

"3(1) No officer shall have an absolute right to compensation for past service or any pension, gratuity or other benefit under this Act.

(2) Where the Yang di-Pertuan Agong is satisfied that an officer has been guilty of negligence, irregularity or misconduct, the Yang diPertuan Agong may reduce or withhold a pension, gratuity or other benefit for which the officer would have been eligible but for the provision of this section."

This provision seems to indicate that being found guilty of misconduct will have an impact the entitlement of the pensionable officers. This provision allows the government to either reduce or withhold the said pension for the officer as a result of the conviction. Therefore, it is clear that being found guilty of misconduct is a high price to pay since the main attraction of working in the public service is for the retirement and pension benefit. Faced with the choice of losing his old aged financial security, the employee may not have any choice but to opt for an optional retirement. ${ }^{72}$ By this, the employee can be assured of receiving pensions. ${ }^{73}$

\section{CONCLUSION}

As discussed above, it is clear that the non-performance of KPI can be used as a basis to terminate or dismiss an employee. It can be a back door to dismissal or termination depending on the situation. The employee must recognise this impact and therefore strive to improve their performance. The employer, on the other hand, must always design the KPI in accordance with the employee's capabilities and constraints.

${ }^{68}$ Section 2 defined the public service.

${ }^{69}$ Sections 8 of the Pensions Act 1980 defined pensionable officers and section 7 dealt with the conferment of pensionable status.

70 (Act 227).

${ }^{71}$ Ibid, section 3.

${ }^{72}$ Ibid, section 12 .

${ }^{73} \mathrm{Ibid}$, section 10 . 
The KPI and its procedures including its appraisals must be clear and understandable by both parties. Justice and fairness must always be embedded in the process, especially in measuring the KIP. The KPI will make it easier for the employer to terminate or dismiss an employee for non-performance because of the extensive documentations, which can be used as evidence for the allegations of non-performance. The remedial measures that are available such as warning, counselling, training, mentoring and so forth will ensure that when an employee is dismissed or terminated, the employer has followed the necessary administrative and legal procedures. 